\section{Petunia Growth Response to Container Substrate Amended with Dewatered Aquaculture Effluent}

\author{
Jason J. Danaher ${ }^{1,3,9}$, Jeremy M. Pickens ${ }^{2,4}$, Jeffrey L. Sibley ${ }^{2,5}$, \\ Jesse A. Chappell ${ }^{1,6}$, Terrill R. Hanson ${ }^{1,7}$, and Claude E. Boyd ${ }^{1,8}$
}

AdDITIONAL INDEX WORDs. waste management, animal waste, floriculture, Petunia $\times$ bybrida

Summary. This experiment evaluated petunia (Petunia $\times$ bybrida 'Celebrity') growth response to amending a commercial potting mix (F3B) with different amounts of dewatered aquaculture effluent $(\mathrm{AE})$ and fertigating with a water-soluble, inorganic fertilizer or municipal water. The experiment was a completely randomized $2 \times 5$ factorial design with eight single-pot replications per treatment. At 39 days after planting $(D A P)$, a significant $(P \leq 0.05)$ substrate and water interaction existed for petunia growth index (GI), bloom count (BC), fresh weight (FW), and dry weight (DW). The $100 \% \mathrm{~F} 3 \mathrm{~B}, 5 \% \mathrm{AE}$, and $10 \% \mathrm{AE}$ substrates benefited with a significantly $(P \leq 0.05)$ greater $\mathrm{BC}, \mathrm{FW}$, and $\mathrm{DW}$ when fertigation was used; however, the water source had no effect on petunia BC, FW, or DW for levels $\geq 25 \%$ AE. Fertigating substrates amended with increasing levels of AE did not improve petunia growth. Conversely, when applying municipal water plant, FW and DW were the greatest using $25 \%$ AE.

A quaculture, the production of aquatic animals and plants for human consumption, is one of the fastest growing sectors of animalbased agriculture (Food and Agriculture Organization of the United Nations, 2010). A decline in wild fisheries coupled with a strong consumer-driven demand for aquaculture products has resulted in the adoption of intensive fish production systems. While aquaculture farms have become more productive, they are proactively looking for methods to mitigate environmental impacts. Recirculating aquaculture systems (RAS) have incorporated modern technology to manage nutrients and solid waste in a controlled environment allowing the producer to maximize

This project was funded by the United Soybean Board through Grant No. 1461.

This research is a portion of a thesis submitted by Jason J. Danaher in fulfilling the degree requirement.

${ }^{1}$ Department of Fisheries and Allied Aquaculture, Auburn University, 203 Swingle Hall, Auburn, AL 36849

${ }^{2}$ Department of Horticulture, Auburn University, 101 Funchess Hall, Auburn, AL 36849

${ }^{3}$ Graduate Research Assistant

${ }^{4}$ Research Associate III

${ }^{5}$ Bohmann Professor of Horticulture

${ }^{6}$ Assistant Professor and Extension Agent

${ }^{7}$ Associate Professor and Extension Agent

${ }^{8}$ Professor and Butler Cunningham Eminent Scholar

${ }^{9}$ Corresponding author. E-mail: jjd0011@auburn.edu. production per unit area and reuse limited freshwater resources through mechanical removal of solids and biofiltration of dissolved wastes. These systems are currently being used to produce popular food species like nile tilapia [Oreochromis niloticus (Azim and Little, 2008)] and Pacific white shrimp [Litopenaeus vannemei (Ray et al., 2010)]. To ensure system sustainability, a RAS discharges dissolved wastes and concentrated organic matter daily. Even though the point of discharge is well defined, the concentrated organic matter and inorganic nutrients are still a liability for the producer (Ebeling et al., 2005). Therefore, identifying management strategies to minimize nutrient loss is important to intensive aquaculture production facilities and the adjacent environment.

While intensive RAS facilities are investigating methods to use discharged wastes, the horticulture industry is searching for alternative soilless substrates for ornamental plant propagation and production. Sphagnum peatmoss (PM) remains extremely important to the U.S. greenhouse industry and is used as a primary component for greenhouse plants because of its superior physical and chemical properties (Fain et al., 2008). However, the demand for PM has increased and transportation costs have escalated from heightened costs of petroleum. In an effort to reduce dependence on PM, the horticulture industry has used alternative soilless mixes for complete replacement (Abad et al., 2002; Arenas et al., 2002; Chavez et al., 2008) or mixed their own substrate with locally available and cost-effective amendments for partial replacement of PM substrates (Arenas et al., 2002; Garcia-Gomez et al., 2002; Guérin et al., 2001).

Few experiments exploit the potential of solid matter in $\mathrm{AE}$ as a substrate amendment for container plants. Boyd and Tucker (1998) report only $25 \%$ to $30 \%$ of the nitrogen applied to an aquaculture production system is harvested with the target species. Uneaten feed or fish excretion of dissolved wastes and fecal matter account for the unused nutrients. Thus, improved nutrient efficiency through integrated agricultural systems is high. Studies have analyzed fish effluent and conclude the nitrogen content and phosphorus levels would make it a good plant nutrient source. Nair (2006) discovered vermicomposted AE used as a potting medium was beneficial to container-grown plants in a greenhouse and would be an effective nutrient source for plants. In addition, Danaher et al. (2011) found tomato (Solanum lycopersicum) seedlings responded positively to different ratios of composted $\mathrm{AE}$ as the sole source of nutrients. Palada et al. (1999) found AE performed as well as other organic or inorganic commercial fertilizers for field production of bell peppers (Capsicum annumm). Therefore, separating

\begin{tabular}{llll}
\hline $\begin{array}{l}\text { Units } \\
\begin{array}{l}\text { To convert U.S. to SI, } \\
\text { multiply by }\end{array}\end{array}$ & U.S. unit & SI unit & $\begin{array}{l}\text { To convert SI to U.S., } \\
\text { multiply by }\end{array}$ \\
\hline 3.7854 & gal & $\mathrm{L}$ & 0.2642 \\
2.54 & inch $(\mathrm{es})$ & $\mathrm{cm}$ & 0.3937 \\
1 & $\mathrm{mmho} / \mathrm{cm}$ & $\mathrm{mS} \cdot \mathrm{cm}^{-1}$ & 1 \\
28.3495 & $\mathrm{oz}$ & $\mathrm{g}$ & 0.0353 \\
1.7300 & $\mathrm{oz} / \mathrm{inch}^{3}$ & $\mathrm{~g} \cdot \mathrm{cm}^{-3}$ & 0.5780 \\
1 & $\mathrm{ppm}$ & $\mathrm{mg} \cdot \mathrm{L}^{-1}$ & 1 \\
$\left({ }^{\circ} \mathrm{F}-32\right) \div 1.8$ & ${ }^{\circ} \mathrm{F}$ & ${ }^{\circ} \mathrm{C}$ & $\left({ }^{\circ} \mathrm{C} \times 1.8\right)+32$
\end{tabular}


the liquid component from the solid component through dewatering discharged $\mathrm{AE}$ and discovering a use for the solids may benefit the horticulture industry as a substrate amendment for container-grown plants.

Integrated production systems are an important production strategy from an environmental perspective because the nutrient output from one production system can provide essential nutrient inputs for another and thus minimizing the environmental impact through on-site recovery and recycling of unused nutrients. The ability to get a double crop (fish + plants) from the same nutrient source will become increasingly important in areas where waste management will be strictly regulated. The aforementioned studies suggest the original effluent stream from RAS should not be thought as an environmental problem, but should be collected and treated as an on-farm resource for horticulture production techniques.

The main objective of this study was to evaluate 'Celebrity' petunia growth in response to partial replacement of a commercially available container mix substituted with different amounts $(0 \%, 5 \%, 10 \%, 25 \%$, and $50 \%)$ of dewatered $\mathrm{AE}$ and watered with either municipal water or a watersoluble, inorganic fertilizer.

\section{Materials and methods}

The AE was collected from an intensive, freshwater RAS producing nile tilapia located at the E.W. Shell Fisheries Center, North Auburn Unit in Auburn, AL. Discharged effluent was directed to an area on the groundcovered with a black permeable $3.2-\mathrm{oz}$ woven polypropylene groundcover where it was allowed to dewater via evaporation under sunlight. Moisture content of the $\mathrm{AE}$ ( $68 \%$ moisture) was determined before amending the commercial potting mix by taking four, 100 -g subsamples and drying them in a forced air oven at $68^{\circ} \mathrm{C}$ for $72 \mathrm{~h}$. Before mixing the substrates, the $\mathrm{AE}$ was manually extruded through a hard plastic netting with a $0.6-\mathrm{cm}$ diamondshaped mesh to reduce the solids cake into a usable form for container production. On 11 Mar. 2011, four substrates were formulated by substituting commercial potting mix (Fafard 3B; Conrad Fafard, Agawam, MA) with 5\%, $10 \%, 25 \%$, and $50 \%$ (by volume) AE. The F3B mix consisted of Canadian sphagnum PM $(50 \%)$, processed pine bark, perlite, vermiculite, starter nutrients, wetting agent, and dolomitic limestone. A composite sample of the $\mathrm{F} 3 \mathrm{~B}$ and $\mathrm{AE}$ was taken and analyzed at the Auburn University Soils Laboratory (Auburn, AL) for chemical properties (Table 1). Saturated media method was used to extract soluble salts, and elements were determined simultaneously by inductively coupled plasma atomic emission spectrometry using a radial spectrometer (VistaMPX; Varian, Palo Alto, CA). The substrate $\mathrm{pH}$ was determined using a bench-top meter (Accumet Model 50; Fisher Scientific, Pittsburgh, PA). Inorganic nitrogen was analyzed according to Sims et al. (1995) and total nitrogen and carbon according to methods described by Kirsten (1979).

Substrate physical properties (Table 2), including total porosity
(TP), container capacity (CC), air space (AS), and bulk density (BD), were determined using the in-pot method described by Yeager et al. (2007) and Chavez et al. (2008). The plastic pots used were $1.3 \mathrm{~L}(15.3-\mathrm{cm}$ diameter; Dillen $^{\mathrm{TM}}$ Products, Middlefield, $\mathrm{OH}$ ), and three replicates were used for each substrate. The nondestructive Virginia Tech pour-through extraction method (Wright, 1986) was used to acquire substrate $\mathrm{pH}$ and electrical conductivity (EC) of substrates $0 \mathrm{DAP}$ and then 16 and 36 DAP using a bench-top multiparameter meter (Accumet Excel XL50, Fisher Scientific). Initial $\mathrm{pH}$ and EC of the water sources were also determined 0 DAP with the bench-top meter (Table 3).

The experiment was performed in a gutter-connected, twin-wall polycarbonate greenhouse at the Paterson

Table 1. Chemical properties from composite samples of commercial potting mix (Fafard 3B; Conrad Fafard, Agawam, MA) and dewatered aquaculture effluent (AE) from a freshwater nile tilapia recirculating production system used as soilless substrates. ${ }^{\mathrm{z}}$

\begin{tabular}{lcc}
\hline & \multicolumn{2}{c}{ Substrate } \\
\cline { 2 - 3 } & Fafard 3B & AE \\
\hline Organic carbon $(\%)$ & 17.1 & 9.3 \\
Total nitrogen $(\%)$ & 0.4 & 1.2 \\
Ammonia-nitrogen $\left(\mathrm{mg} \cdot \mathrm{L}^{-1}\right)^{\mathrm{y}}$ & 29 & 82 \\
Nitrate-nitrogen $\left(\mathrm{mg} \cdot \mathrm{L}^{-1}\right)$ & 58 & 56 \\
Phosphorus $\left(\mathrm{mg} \cdot \mathrm{L}^{-1}\right)$ & 2 & 61 \\
Potassium $\left(\mathrm{mg} \cdot \mathrm{L}^{-1}\right)$ & 133 & 304 \\
Calcium $\left(\mathrm{mg} \cdot \mathrm{L}^{-1}\right)$ & 89 & 178 \\
Magnesium $\left(\mathrm{mg} \cdot \mathrm{L}^{-1}\right)$ & 107 & 146 \\
Iron $\left(\mathrm{mg} \cdot \mathrm{L}^{-1}\right)$ & 1 & 5 \\
pH & 6.0 & 6.4 \\
Electrical conductivity $\left(\mathrm{mS} \cdot \mathrm{cm}^{-1}\right)^{\mathrm{y}}$ & 0.7 & 1.2 \\
\hline
\end{tabular}

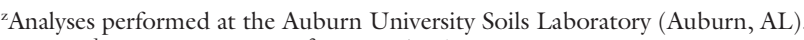

${ }^{\mathrm{y}} \mathrm{l} \mathrm{mg} \cdot \mathrm{L}^{-1}=1 \mathrm{ppm}, 1 \mathrm{mS} \cdot \mathrm{cm}^{-3}=1 \mathrm{mmho} / \mathrm{cm}$.

Table 2. Physical properties of commercial potting mix [Fafard 3B (F3B); Conrad Fafard, Agawam, MA] alone and F3B substituted with different volumes of dewatered aquaculture effluent (AE) from a freshwater nile tilapia production system. ${ }^{2}$

\begin{tabular}{lcccc}
\hline Substrate & $\begin{array}{c}\text { Total porosity } \\
(\mathbf{T P})(\%)^{\mathbf{y}}\end{array}$ & $\begin{array}{c}\text { Container } \\
\text { capacity }(\mathbf{C C})(\%)^{\mathbf{x}}\end{array}$ & $\begin{array}{c}\text { Air space } \\
(\mathrm{AS})(\%)^{\mathbf{w}}\end{array}$ & $\begin{array}{c}\text { Bulk density } \\
(\mathrm{BD})\left(\mathbf{g} \cdot \mathbf{c m}^{-3}\right)^{\mathbf{v}}\end{array}$ \\
\hline $100 \% \mathrm{~F} 3 \mathrm{~B}$ & $62.9 \mathrm{a}^{\mathrm{u}}$ & $41.9 \mathrm{a}$ & $21.0 \mathrm{a}$ & $0.11 \mathrm{c}$ \\
$5 \% \mathrm{AE}$ & $62.8 \mathrm{a}$ & $45.2 \mathrm{a}$ & $17.6 \mathrm{a}$ & $0.12 \mathrm{bc}$ \\
$10 \% \mathrm{AE}$ & $60.0 \mathrm{a}$ & $43.1 \mathrm{a}$ & $16.8 \mathrm{a}$ & $0.12 \mathrm{bc}$ \\
$25 \% \mathrm{AE}$ & $56.1 \mathrm{a}$ & $41.6 \mathrm{a}$ & $14.4 \mathrm{a}$ & $0.15 \mathrm{ab}$ \\
$50 \% \mathrm{AE}$ & $56.7 \mathrm{a}$ & $36.9 \mathrm{a}$ & $19.8 \mathrm{a}$ & $0.18 \mathrm{a}$ \\
Sufficiency range $^{\mathrm{t}}$ & $50-80$ & $45-65$ & $10-30$ & $0.19-0.70$ \\
\hline
\end{tabular}

${ }^{2}$ Analyses performed using methods described by Yeager et al. (2007) and Chavez et al. (2008).

$\mathrm{y} \mathrm{TP}=\mathrm{CC}+\mathrm{AS}$

${ }^{\mathrm{x}} \mathrm{CC}=($ wet weight - oven $\mathrm{DW}) \div$ volume of the sample

wAS $=$ volume of water drained from the sample $\div$ volume of the sample.

vBD after forced air drying at $105^{\circ} \mathrm{C}\left(221.0^{\circ} \mathrm{F}\right)$ for $48 \mathrm{~h} ; 1 \mathrm{~g} \cdot \mathrm{cm}^{-3}=0.5780 \mathrm{oz} / \mathrm{inch}^{3}$.

"Mean within the same column followed by a different letter are significantly different by Tukey's test $P \leq 0.05$ $(n=3)$.

${ }^{t}$ Sufficiency ranges reported by Yeager et al. (2007). 
Greenhouse Complex, Auburn University, Auburn, AL. Temperature controls in the greenhouse were set to maintain a temperature between $19^{\circ} \mathrm{C}$ and $26^{\circ} \mathrm{C}$, and plants were grown under natural lighting. The trial was designed as a $2 \times 5$ factorial evaluating two water sources (municipal water and water-soluble fertilizer) and five different substrates. The experiment was a completely randomized design with eight single-pot replications for each treatment. On 11 Mar., one plug from a 200-cell flat of 'Celebrity' petunia (Young's Plant Farm, Auburn, AL) was planted in each 1.3-L plastic pot containing the aforementioned substrates. All pots were placed on

Table 3. The $\mathrm{pH}$ and electrical conductivity (EC) of commercial potting mix [Fafard 3B (F3B); Conrad Fafard, Agawam, MA] and F3B amended with different volumes of dewatered aquaculture effluent (AE) from a freshwater nile tilapia production system at 0,16 , and $36 \mathrm{~d}$ after planting (DAP) and SPAD readings at $36 \mathrm{DAP}$.

\begin{tabular}{|c|c|c|c|c|c|c|c|}
\hline \multirow[b]{2}{*}{ Main effect } & \multicolumn{3}{|c|}{$\mathrm{pH}^{\mathrm{z}}$} & \multicolumn{3}{|c|}{$\mathrm{EC}\left(\mathrm{mS} \cdot \mathrm{cm}^{-1}\right)^{\mathrm{z}}$} & \multirow{2}{*}{$\frac{\text { SPAD }^{y}}{36 \mathrm{DAP}^{\mathrm{D}}}$} \\
\hline & $0 \mathrm{DAP}$ & 16 DAP & $36 \mathrm{DAP}$ & $0 \mathrm{DAP}$ & $16 \mathrm{DAP}$ & $36 \mathrm{DAP}$ & \\
\hline \multicolumn{8}{|l|}{ Substrate } \\
\hline $100 \% \mathrm{~F} 3 \mathrm{~B}$ & $6.0 c^{x}$ & $6.7 \mathrm{a}$ & $6.0 \mathrm{a}$ & $0.7 \mathrm{~b}$ & $2.3 \mathrm{~b}$ & $0.8 \mathrm{~b}$ & $44.1 \mathrm{a}$ \\
\hline $5 \% \mathrm{AE}$ & $6.3 \mathrm{~b}$ & $6.1 \mathrm{c}$ & $6.1 \mathrm{a}$ & $0.6 \mathrm{~b}$ & $3.4 \mathrm{ab}$ & $0.8 \mathrm{~b}$ & $45.1 \mathrm{a}$ \\
\hline $10 \% \mathrm{AE}$ & $6.4 \mathrm{ab}$ & $6.1 \mathrm{c}$ & $6.1 \mathrm{a}$ & $0.6 \mathrm{~b}$ & $4.4 \mathrm{a}$ & $1.0 \mathrm{ab}$ & $44.7 \mathrm{a}$ \\
\hline $25 \% \mathrm{AE}$ & $6.5 \mathrm{a}$ & $6.0 \mathrm{c}$ & $6.2 \mathrm{a}$ & $0.8 \mathrm{~b}$ & $5.6 \mathrm{a}$ & $1.1 \mathrm{ab}$ & $43.2 \mathrm{a}$ \\
\hline $50 \% \mathrm{AE}$ & $6.3 \mathrm{~b}$ & $6.4 \mathrm{~b}$ & $6.3 \mathrm{a}$ & $1.5 \mathrm{a}$ & $5.2 \mathrm{a}$ & $1.5 \mathrm{a}$ & $42.5 \mathrm{a}$ \\
\hline \multicolumn{8}{|l|}{ Water } \\
\hline Municipal & $6.6 \mathrm{a}$ & $6.2 \mathrm{a}$ & $6.4 \mathrm{a}$ & $0.2 \mathrm{~b}$ & $4.1 \mathrm{a}$ & $0.6 \mathrm{~b}$ & $41.9 \mathrm{~b}$ \\
\hline Fertilizer & $6.1 \mathrm{~b}$ & $6.3 \mathrm{a}$ & $5.8 \mathrm{~b}$ & $1.6 \mathrm{a}$ & $3.9 \mathrm{a}$ & $1.7 \mathrm{a}$ & $46.0 \mathrm{a}$ \\
\hline \multicolumn{8}{|l|}{ Significance $^{\mathrm{x}}$} \\
\hline Substrate & * & *** & NS & $*$ & $* * *$ & $* * *$ & NS \\
\hline Water & ** & NS & $* * *$ & *** & NS & $* * *$ & $* * *$ \\
\hline $\begin{array}{l}\text { Substrate } \\
\text { and water }\end{array}$ & - & NS & NS & - & NS & NS & NS \\
\hline
\end{tabular}

${ }^{\mathrm{z}}$ Initial substrate $\mathrm{pH}$ and $\mathrm{EC}$ before water added to treatments obtained by pour-through method; initial water $\mathrm{pH}$ and $\mathrm{EC}$ before applying to substrates; $\mathrm{pH}$ and $\mathrm{EC}$ of solution 16 and $36 \mathrm{DAP}$ obtained by the pour-through method; $1 \mathrm{mS} \cdot \mathrm{cm}^{-1}=1 \mathrm{mmho} / \mathrm{cm}$.

y Leaf greenness of three recently mature leaves per plant was quantified with a chlorophyll meter (SPAD-502; Minolta Camera Co., Ramsey, NJ).

'Mean separation of main effects within the same column followed by a different letter are significantly different by Tukey's test at $P \leq 0.05(*), 0.01\left(^{* *}\right)$, or $0.001(* *)$; NS $=$ nonsignificant $(n=8)$.

raised benches and for the first week all pots were watered with municipal water as needed. Thereafter, pots were watered as needed according to treatment with either municipal water or fertigated using a Dosatron ${ }^{\circledR}$ (Dosatron International, Clearwater, FL) injector at $250 \mathrm{mg} \cdot \mathrm{L}^{-1}$ nitrogen with a watersoluble $20 \mathrm{~N}-4.4 \mathrm{P}-16.6 \mathrm{~K}$ fertilizer (SDT Industries, Winnsboro, LA) containing chelated micronutrients at each watering. All treatments were watered until substrate reached saturation (i.e., until water leached from the bottom of the pot).

At $36 \mathrm{DAP}$, leaf greenness was quantified for all plants using a chlorophyll meter (SPAD-502; Minolta Camera Co., Ramsey, NJ) and taking the average reading of three mature leaves per plant (Table 3). At $39 \mathrm{DAP}$, all plants were measured for GI [GI = (height + width + perpendicular width) $\div 3$ ] and BC (open flowers and unopened buds showing color) (Table 4). Plant shoots were then removed from the container at the substrate surface and $\mathrm{FW}$ was recorded. Shoots were then oven dried at $68^{\circ} \mathrm{C}$ for $72 \mathrm{~h}$ to determine DW. The FW and DW included flowers (Table 4).

Two-way analysis of variance (ANOVA) was used to determine the main effect of substrate and water on petunia growth (Table 4). Harvest data did not fulfill the assumption of homoscedasticity required for analysis with ANOVA (Bhujel, 2008); therefore,

Table 4. Effect of substrate and water interaction on 'Celebrity' petunia growth index (GI), bloom count (BC), fresh weight (FW), and dry weight (DW) of shoots and flowers $39 \mathrm{~d}$ after planting in commercial potting mix [Fafard 3B (F3B); Conrad Fafard, Agawam, MA] and F3B amended with different volumes of dewatered aquaculture effluent (AE) from a freshwater nile tilapia production system.

\begin{tabular}{|c|c|c|c|c|c|c|c|c|}
\hline & \multicolumn{2}{|c|}{$\mathrm{GI}(\mathrm{cm})^{\mathrm{z}}$} & \multicolumn{2}{|c|}{$\mathrm{BC}(\text { no. })^{\mathrm{x}}$} & \multicolumn{2}{|c|}{ FW $(g)^{w}$} & \multicolumn{2}{|c|}{$\mathrm{DW}(\mathrm{g})$} \\
\hline & Fertilizer $^{\mathrm{y}}$ & Municipaly $^{y}$ & Fertilizer & Municipal & Fertilizer & Municipal & Fertilizer & Municipal \\
\hline \multicolumn{9}{|l|}{ Substrate } \\
\hline $5 \% \mathrm{AE}$ & $40.1 \mathrm{Aa}$ & $33.1 \mathrm{Ba}$ & $42.5 \mathrm{Aa}$ & $29.4 \mathrm{Bab}$ & $129.1 \mathrm{Aa}$ & $60.0 \mathrm{Bc}$ & $21.5 \mathrm{Aa}$ & $14.5 \mathrm{Bbc}$ \\
\hline $10 \% \mathrm{AE}$ & $35.1 \mathrm{Aa}$ & $34.9 \mathrm{Aa}$ & $38.9 \mathrm{Aa}$ & $29.9 \mathrm{Bab}$ & $118.9 \mathrm{Aa}$ & $75.3 \mathrm{Bbc}$ & $19.9 \mathrm{Aa}$ & $16.4 \mathrm{Bab}$ \\
\hline $25 \% \mathrm{AE}$ & $39.2 \mathrm{Aa}$ & $35.3 \mathrm{Ba}$ & $41.0 \mathrm{Aa}$ & $38.3 \mathrm{Aa}$ & $120.8 \mathrm{Aa}$ & 109.1 Aa & $20.8 \mathrm{Aa}$ & $19.0 \mathrm{Aa}$ \\
\hline Substrate & \multicolumn{2}{|c|}{ NS } & \multicolumn{2}{|c|}{$* * *$} & \multicolumn{2}{|c|}{$* * *$} & \multicolumn{2}{|c|}{$* * *$} \\
\hline Water & \multicolumn{2}{|c|}{$* * *$} & \multicolumn{2}{|c|}{$* * *$} & \multicolumn{2}{|c|}{$* * *$} & \multicolumn{2}{|c|}{$* * *$} \\
\hline Substrate and water & \multicolumn{2}{|c|}{ * } & \multicolumn{2}{|c|}{$* *$} & \multicolumn{2}{|c|}{$* * *$} & \multicolumn{2}{|c|}{$* * *$} \\
\hline
\end{tabular}

${ }^{2} \mathrm{GI}=($ height + width + perpendicular width $) \div 3 ; 1 \mathrm{~cm}=0.3937$ inch

${ }^{y}$ Fertilizer $=20 \mathrm{~N}-4.4 \mathrm{P}-16.6 \mathrm{~K}$, municipal $=$ Auburn, AL, city water.

xOpen flowers and unopened buds showing color.

${ }^{\mathrm{w}} \mathrm{l} \mathrm{g}=0.0353 \mathrm{oz}$

${ }^{v}$ For each parameter values within row followed by different lower case letters are significantly different for pairwise comparisons of substrate within each level combination of water by Bonferroni adjusted $\alpha$-level $(\alpha=0.05, n=8)$.

For each parameter values within column followed by different upper case letters are significantly different for pairwise comparisons of water within each level combination of substrate by Bonferroni adjusted $\alpha$-level $(\alpha=0.05, n=8)$.

${ }^{u} P \leq 0.05\left({ }^{*}\right), 0.01\left({ }^{*}\right)$, or $0.001\left({ }^{* *}\right)$ based on two-way analyses of variance $(n=8)$; NS = nonsignificant. 
GI, FW, and DW were transformed before analysis using the base- $10 \log$ arithm transformation. The $\mathrm{BC}$ data were transformed using the square root transformation. The transformed data were analyzed in SPSS (version 16.0; IBM Corp., Armonk, NY); however, the data were presented in the untransformed form to facilitate interpretation. If a significant interaction existed $(P \leq 0.05)$, pairwise comparisons on the individual group means within each simple effect were conducted and means were separated using the Bonferroni adjusted $\alpha$-level $(P \leq 0.05)$. If no significant $(P>0.05)$ statistical interaction was identified, the main effects of substrate and water were analyzed separately and the means were separated by Tukey's test $(P \leq 0.05)$.

\section{Results and discussion}

There was no difference in TP, CC, or AS among substrates, which averaged $59.7 \%, 41.7 \%$, and $17.9 \%$, respectively (Table 2); however, BD increased as amounts of AE increased. The BD increases as the amount of animal-based wastes used to amend the substrate increases (Atiyeh et al., 2001 ). The physical properties of substrates in this experiment were at the minimum recommend ranges for container-grown plants. Yeager et al. (2007) suggest $55 \%$ to $80 \%, 45 \%$ to $65 \%, 10 \%$ to $30 \%$, and 0.19 to $0.70 \mathrm{~g} \cdot \mathrm{cm}^{-3}$ for $\mathrm{TP}, \mathrm{CC}, \mathrm{AS}$, and $\mathrm{BD}$, respectively.

There was a difference among the $\mathrm{pH}$ and EC of substrates 0 DAP (Table 3). These differences reflect the chemical properties of substrates before any watering. The $\mathrm{pH}$ of substrates amended with AE increased while the $\mathrm{pH}$ of $100 \% \mathrm{~F} 3 \mathrm{~B}(6.0)$ was less than all other substrates. The initial $\mathrm{EC}$ of $50 \% \mathrm{AE}\left(1.5 \mathrm{mS} \cdot \mathrm{cm}^{-1}\right)$ was greater than all other substrates 0 DAP. There was a difference between the $\mathrm{pH}$ and $\mathrm{EC}$ of the water source 0 DAP (Table 3 ). These differences reflect the chemical properties of each water source at the start of the experiment. The $\mathrm{pH}$ of the municipal water (6.6) was greater than the fertigation water (6.1). Conversely, the initial EC of the municipal water $\left(0.2 \mathrm{mS} \cdot \mathrm{cm}^{-1}\right)$ was less than the fertigation water $\left(1.6 \mathrm{mS} \cdot \mathrm{cm}^{-1}\right)$. The injection of the $20 \mathrm{~N}-4.4 \mathrm{P}-16.6 \mathrm{~K}$ fertilizer into the municipal water supply to create the fertigation solution resulted in a more acidic $\mathrm{pH}$ and considerable increase in the EC concentration.
At 16 DAP, there was no substrate and water interaction for $\mathrm{pH}$ or EC (Table 3). The main effect of water did not affect $\mathrm{pH}$ or EC; however, the main effect of substrate affected treatment $\mathrm{pH}$ and $\mathrm{EC} 16 \mathrm{DAP}$. The $\mathrm{pH}$ of $100 \% \mathrm{~F} 3 \mathrm{~B}(6.7)$ was greater than all other substrates. The $\mathrm{pH}$ of $50 \% \mathrm{AE}$ (6.4) was greater than $5 \% \mathrm{AE}$ (6.1), 10\% $\mathrm{AE}$ (6.1), and 25\% $\mathrm{AE}$ (6.0) substrates, but the latter were not different from one another. Substrates amended with greater than or equal to $10 \% \mathrm{AE}$ were similar and had an average EC of $5.1 \mathrm{mS} \cdot \mathrm{cm}^{-1}$, which was greater than $100 \% \mathrm{~F} 3 \mathrm{~B}\left(2.3 \mathrm{mS} \cdot \mathrm{cm}^{-1}\right)$. The AE-amended substrates may have been experiencing a period of biological and physical breakdown of the organic wastes, thus decreasing $\mathrm{pH}$ and increasing salt concentrations of container leachate (Table 3). Other container experiments (Dede et al., 2006; Lu et al., 2008) have observed a similar trend with substrates amended with organic wastes. In addition, microbial activity in the substrate may have influenced chemical parameters (Atiyeh et al., 2001). Nonetheless, we are unable to explain why EC concentration may have increased for the $100 \% \mathrm{~F} 3 \mathrm{~B}$ substrate at $16 \mathrm{DAP}$. The watering method remained consistent throughout the experiment, but it may be possible the volume of leachate temporarily changed before sampling chemical properties $16 \mathrm{DAP}$. If leachate volume was reduced, then accumulation of soluble salts could have occurred in the container and were later quantified with the pourthrough method 16 DAP. Also, plant uptake of nutrients may have changed from 16 to 36 DAP. The uptake of nutrients from 16 to 36 DAP may have increased to support continued plant growth and resulted in a decrease in EC concentration during this time period.

There was no substrate and water interaction on $\mathrm{pH}$ or $\mathrm{EC}$ of treatments 36 DAP (Table 3 ). The main effect of water did affect $\mathrm{pH}$ and $\mathrm{EC}$ of treatments 36 DAP. The $\mathrm{pH}$ of treatments receiving fertigation (5.8) was less compared with treatments receiving municipal water (6.4). Treatments receiving municipal water were slightly above optimal $\mathrm{pH}$ (5.4 to 6.2) for petunia (Argo, 2004). The EC of treatments receiving fertigation $\left(1.7 \mathrm{mS} \cdot \mathrm{cm}^{-1}\right)$ were higher compared with treatments receiving municipal water $\left(0.6 \mathrm{mS} \cdot \mathrm{cm}^{-1}\right) 36 \mathrm{DAP}$. The main effect of substrate did not affect $\mathrm{pH} 36 \mathrm{DAP}$ with an average $\mathrm{pH}$ of 6.1 for all substrates. The EC concentration of $50 \% \mathrm{AE}\left(1.5 \mathrm{mS} \cdot \mathrm{cm}^{-1}\right)$ was greater than $100 \% \mathrm{~F} 3 \mathrm{~B}\left(0.8 \mathrm{mS} \cdot \mathrm{cm}^{-1}\right)$ and $5 \% \mathrm{AE}\left(0.8 \mathrm{mS} \cdot \mathrm{cm}^{-1}\right)$. The EC concentration of $10 \% \mathrm{AE}\left(1.0 \mathrm{mS} \cdot \mathrm{cm}^{-1}\right)$ and $25 \% \mathrm{AE}\left(1.1 \mathrm{mS} \cdot \mathrm{cm}^{-1}\right)$ was equal to all other substrates. The relationship observed between increasing amounts of $\mathrm{AE}$ and increasing EC concentration of container leachate may have resulted from continued breakdown and release of salts 36 DAP.

At $36 \mathrm{DAP}$, there was no substrate and water interaction on petunia leaf SPAD readings (Table 4 ). The main effect of substrate did not affect leaf SPAD readings with an average of 43.9 for all substrates; however, the main effect of water resulted in different leaf SPAD readings 36 DAP. Leaf SPAD reading for treatments receiving fertilizer (46.0) were greater than treatments receiving municipal water (41.9). There is often a strong correlation between SPAD measurements and leaf nitrogen content (Sibley et al., 1996). This experiment did not analyze leaf tissue postharvest to determine nutrient concentrations in the tissue, and it is possible the readily available macronutrients and micronutrients in the fertigation solution resulted in improved chlorophyll concentration of petunia.

In addition, we hypothesize the availability of iron may have affected the leaf greenness levels. Plants receiving municipal water were observed to have mild interveinal chlorosis compared with plants receiving fertigation. Treatments receiving fertigation were provided a dilute concentration of iron EDTA chelate and other micronutrients at each watering because the commercial fertilizer did contain chelated forms of micronutrients. In addition, the $\mathrm{pH}$ of fertigated treatments remained within an acceptable range for an iron-inefficient plant group like petunia, whereas treatments receiving municipal water were dependent on the initial iron concentration in the substrate and the chemical properties, specifically $\mathrm{pH}$, of the substrate to maintain iron availability. The $\mathrm{pH}$ of treatments receiving municipal water (6.4) 36 DAP were slightly greater than the optimal range (5.4 to 6.2) recommended for petunia (Argo, 2004). Peryea and Kammereck (1997) 
proposed a SPAD chlorophyll meter could be used as an unbiased means to assess iron deficiency. In addition, Álvarez-Fernández et al. (2005) also found a high correlation between iron concentration in the leaf and leaf chlorosis using a SPAD meter. Future experiments should perform postharvest tissue analysis to evaluate tissue nutrient concentration. Specifically, the addition of micronutrients to substrates amended with AE should be assessed on leaf chlorophyll when only municipal water is applied.

At $39 \mathrm{DAP}$, there was a substrate and water interaction for petunia GI, BC, FW, and DW (Table 4). The $100 \% \mathrm{~F} 3 \mathrm{~B}, 5 \% \mathrm{AE}$, and $25 \% \mathrm{AE}$ substrate treatments had a greater GI when fertilizer was applied rather than municipal water. For $10 \%$ and $50 \% \mathrm{AE}$, the water source had no effect on GI at harvest. A grower fertigating with 250 $\mathrm{mg} \cdot \mathrm{L}^{-1}$ nitrogen would not have to amend F3B with $\mathrm{AE}$ to expect an improvement in GI, but amending the commercial substrate up to $50 \%$ container volume did not negatively impact petunia GI either.

At $39 \mathrm{DAP}, 100 \% \mathrm{~F} 3 \mathrm{~B}, 5 \% \mathrm{AE}$, and $10 \%$ AE substrates had a greater $\mathrm{BC}$ when fertilizer was applied instead of municipal water (Table 4 ). For $25 \%$ and $50 \% \mathrm{AE}$, the water source had no effect on BC at harvest. A grower fertigating with $250 \mathrm{mg} \cdot \mathrm{L}^{-1}$ nitrogen would not observe improvements in $\mathrm{BC}$ if amending $\mathrm{F} 3 \mathrm{~B}$ up to $50 \%$ container volume, but amending the commercial substrate with AE would not appear to be detrimental to petunia BC either. However, if only municipal water was applied to the petunia, a grower could amend F3B with as little as $5 \% \mathrm{AE}$ and maximize BC using 25\% AE. Amending F3B with $25 \% \mathrm{AE}$ and watering with municipal water would result in significant improvements compared with the combination of municipal water and $100 \% \mathrm{~F} 3 \mathrm{~B}$. Incorporating $\mathrm{AE}$ into F3B would have increased the initial nitrogen content of the substrate (Table 1), and nitrogen concentration was found to affect petunia flower development (James and van Iersel, 2001). In addition, Arancon et al. (2008) observed maximum number of flowers in substrates amended with 30\% to $40 \%$ vermicompost and at levels greater than $40 \%$ vermicompost a decrease in flower production was observed; however, we did not see a difference in BC up to $50 \% \mathrm{AE}$.

At $39 \mathrm{DAP}$, petunias grown in $100 \% \mathrm{~F} 3 \mathrm{~B}, 5 \% \mathrm{AE}$, and $10 \% \mathrm{AE}$ substrates had a greater FW and DW when fertigated with $250 \mathrm{mg} \cdot \mathrm{L}^{-1}$ nitrogen compared with municipal water (Table 4). However, the advantage of using a combination of AE and fertigation only improved petunia growth up to $25 \% \mathrm{AE}$ with a noticeable decrease in FW and DW at 50\% AE. For $25 \% \mathrm{AE}$ and $50 \% \mathrm{AE}$, the water source had no effect on FW and DW at harvest. Additionally, this study demonstrated amending F3B with AE up to $25 \%$ container volume did not improve petunia FW and DW under fertigation (Table 4 ). But there was no negative impact either indicating it may be safe to amend F3B up to $25 \%$ container volume without impacting FW or DW. Fertigating 50\% AE led to noticeable decreases in petunia FW and DW. We suspect the petunias grown in $50 \% \mathrm{AE}$ and receiving inorganic nutrients were unable to provide a salt buffering capacity and protection for the root system (Hicklenton et al., 2001; Lu et al., 2008). Conversely, when only municipal water was supplied improved petunia FW and DW were recorded with increasing amounts of AE up to $50 \%$ container volume. A grower applying municipal water would maximize plant FW using 25\% AE, but would begin to observe a noticeable decrease at levels less than or equal to $10 \% \mathrm{AE}$ (Table 4 ). There was no difference in petunia DW at levels greater than or equal to $10 \% \mathrm{AE}$, but $100 \% \mathrm{~F} 3 \mathrm{~B}$, and $5 \% \mathrm{AE}$ were observed to have a noticeable decrease in DW compared with $25 \%$ AE.

In this experiment, different growth responses of 'Celebrity' petunia occurred when grown with specific combinations of amended substrate under fixed water regimes. Composted livestock waste from the cattle (Inbar et al., 1993; Jayasinghe et al., 2010), swine (Atiyeh et al., 2001; Atiyeh et al., 2002; Ribeiro et al., 2007), and poultry (Kelleher et al., 2002; Tyler et al., 1993) industries has also been used to amend traditional substrates for container-grown plants and reuse organic wastes generated from production facilities. Experiments using organic wastes to amend container substrate have shown a low organic waste ( $5 \%$ to $40 \%$ ) ratio in the blend often promotes better plant growth than in non-amended blends (Atiyeh et al., 2002; Lu et al., 2008); however, the benefit can disappear at levels greater than $50 \%$ resulting in reduced plant growth (Chong and Cline, 1993; Nkongolo et al., 2000; Shiralipour et al., 1992; Wilson et al., 2001).

A similar trend existed for $\mathrm{F} 3 \mathrm{~B}$ amended with different ratios of $\mathrm{AE}$; however, the water regime also $\mathrm{di}^{-}$ rectly impacted overall plant growth and its effect on growth indices was dependent on the container substrates used in this experiment. When municipal water was applied, improvements were observed in petunia BC, FW, and DW when F3B was amended at greater than or equal to $5 \%, 25 \%$, and $10 \%$ container volume, respectively. The AE had a stimulating effect on petunia growth acting as the main source of nutrients (Table 1) in treatments receiving only municipal water. Our findings coincide with previous experiments (Danaher et al., 2011; Nair, 2006; Palada et al., 1999) reporting AE can benefit plant growth and production. As a final point, this experiment should be reassessed by amending a peat substrate mix devoid of starter nutrients. Under this circumstance, larger differences in petunia growth may be observed among treatments.

\section{Conclusion}

Dewatered effluent from a RAS has potential to be used as an amendment in commercially available substrates and proved to be beneficial to container-grown petunias. In addition, aquaponic production of floriculture crops is possible using the solids fraction of AE. These results can expand upon traditional aquaponic strategies of using only the liquid fraction of $\mathrm{AE}$ as a plant nutrient source; thus, helping to alleviate waste management issues. Future experiments should assess alternative floriculture crops, and the supplementation of micronutrients to substrates amended with AE when only municipal water is applied.

\section{Literature cited}

Abad, M., P. Noguera, R. Puchades, A. Maquieira, and V. Noguera. 2002. Physicochemical and chemical properties of some coconut coir dusts for use as a peat 
substitute for containerized ornamental plants. Bioresour. Technol. 82:241-245.

Álvarez-Fernández, A., S. García-Marco, and J.J. Lucena. 2005. Evaluation of syntheticiron(III) chelates (EDDHA/ $\mathrm{Fe} 3+$, EDDHMA/Fe3+ and the novel EDDHSA $/ \mathrm{Fe} 3+$ ) to correct iron chlorosis. Eur. J. Agron. 22:119-130.

Arancon, N.Q., C.A. Edward, A. Babenko, J. Cannon, and J.D. Metzger. 2008. Influence of vermicomposts produced by microorganisms from cattle manure, food waste and paper waste on the germination, growth and flowering of petunias in the greenhouse. Appl. Soil Ecol. 39:91-98.

Arenas, M., C.S. Vavrina, J.A. Cornell, E.A. Hanlon, and G.J. Hochmuth. 2002. Coir as an alternative to peat in media for tomato transplant production. HortScience 37:309-312.

Argo, B. 2004. Understanding pH management and plant nutrition. Part 4. Substrates. J. Intl. Phalaenopsis Alliance 13: $1-5$.

Atiyeh, R.M., C.A. Edwards, S. Subler, and J.D. Metzger. 2001. Pig manure vermicompost as a component of a horticultural bedding plant medium: Effects on physicochemical properties and plant growth. Bioresour. Technol. 78:11-20.

Atiyeh, R.M., N.Q. Arancon, C.A. Edwards, and J.D. Metzger. 2002. The influence of earthworm-processed pig manure on the growth and productivity of marigolds. Bioresour. Technol. 81:103108.

Azim, M.E. and D.C. Little. 2008. The biofloc technology (BFT) in indoor tanks: Water quality, biofloc composition, and growth and welfare of nile tilapia (Oreochromis niloticus). Aquaculture 283:29-35.

Bhujel, R.C. 2008. Statistics for aquaculture. Wiley-Blackwell, Ames, IA.

Boyd, C.E. and C.S. Tucker. 1998. Pond aquaculture water quality management. Kluwer Academic Publishers, Boston, MA.

Chavez, W., A. Di Benedetto, G. Civeira, and R. Lavado. 2008. Alternative soilless media for growing Petunia $\times$ bybrida and Impatiens wallerana: Physical behavior, effect of fertilization and nitrate losses. Bioresour. Technol. 99:8082-8087.

Chong, C. and R.A. Cline. 1993. Response of four ornamental shrubs to container substrate amended with two types of raw paper mill sludge. HortScience 28:807-809.

Danaher, J.J., E. Pantanella, J.E. Rakocy, R.C. Shultz, and D.S. Bailey. 2011.
Dewatering and composting aquaculture waste as a growing medium in the nursery production of tomato plants. Acta Hort. 891:223-229.

Dede, O.H., K. Gulgun, O. Saim, and A. Celeb. 2006. Effects of organic waste substrates on the growth of impatiens. Turk. J. Agr. For. 30:375-381.

Ebeling, J.M., K.L. Rishel, and P.L. Sibrell. 2005. Screening and evaluation of polymers as flocculation aids for the treatment of aquacultural effluents. Aquacult. Eng. 33:235-249.

Fain, G.B., C.H. Gilliam, J.L. Sibley, C.R. Boyer, and A.L. Witcher. 2008. Wholetree substrate and fertilizer rate in production of greenhouse grown petunia (Petunia $\times$ bybrida Vilm.) and marigold (Tagetes patula L.). HortScience 43:700705.

Food and Agriculture Organization of the United Nations. 2010. The State of World Fisheries and Aquaculture. 2010. 15 Feb. 2010. <http://www. fao.org/docrep/ 013/il820e/il820e. $\mathrm{pdf}>$.

Garcia-Gomez, A., M.P. Bernal, and A. Roig. 2002. Growth of ornamental plants in two composts prepared from agroindustrial wastes. Bioresour. Technol. 83: 81-87.

Guérin, V., F. Lemaire, O. Marfà, R. Caceres, and F. Giuffrida. 2001. Growth of Vibrium tinus in peat-based and peatsubstitute growing media. Sci. Hort. 89:129-142.

Hicklenton, P.R., V. Rodd, and P.R. Warman. 2001. The effectiveness and consistency of source separated municipal solid waste and bark composts as components of container growing media. Sci. Hort. 91:365-378.

Inbar, Y., Y. Hadar, and Y. Chen. 1993. Recycling of cattle manure: The composting process and characterization of maturity. J. Environ. Qual. 22:857 863.

James, E.C. and M.W. van Iersel. 2001. Fertilizer concentration affects growth and flowering of subirrigated petunias and begonias. HortScience 37:4044.

Jayasinghe, G.Y., I.D. Liyana Arachchi, and Y. Tokashiki. 2010. Evaluation of containerized substrates developed from cattle manure compost and synthetic aggregates for ornamental plant production as a peat alternative. Resour. Conserv. Recycling 54:1412-1418.

Kelleher, B.P., J.J. Leahy, A.M. Henihan, T.F. O'Dwyer, D. Sutton, and M.J. Leahy. 2002. Advances in poultry litter disposal technology: A review. Bioresour. Technol. 83:27-36.

Kirsten, W.J. 1979. Automated methods for the determination of carbon, hydrogen, nitrogen, and sulfur alone in organic and inorganic materials. Anal. Chem. 51:1173-1179.

Lu, W., X. Yang, J.L. Sibley, C.H. Gilliam, J.S. Bannon, and Y. Zhang. 2008. Utilization of mixed municipal solid waste compost as a soilless potting component in greenhouse production of four floricultural crops. J. Environ. Hort. 26: 75-79.

Nair, D.N.S. 2006. Recycling aquacultural waste through horticultural greenhouse production as a resource recovery approach. Virginia Polytechnic State Univ., Blacksburg, MS Thesis.

Nkongolo, N.V., J. Caron, F. Gauthier, and M. Yamada. 2000. Organic wastes for improving soil physical conditions and enhancing plant growth in container substrates, p. 97-113. In: H. Xu, J.F. Parr, and H. Umemura (eds.). Nature farming and microbial applications. Food Products Press, Binghamton, NY.

Palada, M.C., W.M. Cole, and S.M.A. Crossman. 1999. Influence of effluents from intensive aquaculture and sludge on growth and yield of bell peppers. J. Sustain. Agr. 14:85-103.

Peryea, F. and R. Kammereck. 1997. Use of Minolta SPAD-502 chlorophyll meter to quantify the effectiveness of mid-summer trunk injection of iron on chlorotic pear trees. J. Plant Nutr. 20: 1457-1463.

Ray, A.J., K.S. Dillon, and J.M. Lotz. 2010. Water quality dynamics and shrimp (Litopenaeus vannamei) production in intensive, mesohaline culture systems with two levels of biofloc management. Aquacult. Eng. 45:127136.

Ribeiro, H.M., A.M. Romero, H. Pereira, P. Borges, F. Cabral, and E. Vasconcelos. 2007. Evaluation of a compost obtained from forestry wastes and solid phase of pig slurry as a substrate for seedlings production. Bioresour. Technol. 98:32943297.

Shiralipour, A., D.B. McConnel, and W.H. Smith. 1992. Use and benefits of MSW compost: A review and assessment. Biomass Bioenergy 3:267-279.

Sibley, J.L., D.J. Eakes, C.H. Gilliam, G.J. Keever, W.A. Dozier, Jr., and D.G. Himelrick. 1996. Foliar SPAD-502 meter values, nitrogen levels, and extractable chlorophyll for red maple selections. HortScience 31:468-470. 
Sims, G.K., T.R. Ellsworth, and R.L. Mulvaney. 1995. Microscale determination of inorganic nitrogen in water and soil extracts. Commun. Soil Sci. Plant Anal. 26:303-316.

Tyler, H.H., S.L. Warren, T.E. Bilderback, and W.C. Fonteno. 1993. Composted turkey litter: I. Effect on chemical and physical properties of a pine bark substrate. J. Environ. Hort. 11:131136.

Wilson, S.B., P.J. Stoffella, and D.A. Graetz. 2001. Use of compost as a media amendment for containerized production of two subtropical perennials. J. Environ. Hort. 19:37-42.
Wright, R.D. 1986. The pour-through nutrient extraction procedure. HortScience 21:227-229.

Yeager, T., T. Bilderback, D. Fare, C. Gilliam, J. Lea-Cox, A. Niemiera, J. Ruter, K. Tilt, S. Warren, T. Whitwell, and R. Wright. 2007. Best management practices: Guide for producing nursery crops. 2nd ed. Southern Nursery Assn., Atlanta, GA. 